\title{
Boat anchoring pressure on coastal seabed: quantification and bias estimation using AIS data
}

\author{
Authors : Deter Julie ${ }^{\mathrm{a}, \mathrm{b}}$, Lozupone Xavier ${ }^{\mathrm{a}}$, Inacio Adrien ${ }^{\mathrm{a}, \mathrm{b}}$, Boissery Pierre $^{\mathrm{c}}, \underline{\text { Holon Florian }}^{\mathrm{a}}$
}

Affiliations :

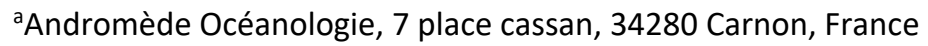

bUMR 5554 -ISEM, campus triolet de l'Université Montpellier, place Eugène Bataillon, 34095 Montpellier cedex 05, France

'Agence de l'eau Rhône-Méditerranée-Corse, immeuble le Noailles, 62 La Canebière, 13001 Marseille, France

Corresponding author: Julie Deter

Andromède océanologie, 7 place Cassan, 34280 Carnon, France

E-mail: julie.deter@andromede-ocean.com

\section{Abstract (150 words)}

Global shipping is economically important, but has many adverse environmental effects. Anchoring contributes greatly to this adverse impact, as it is responsible for mechanical disturbance of highly sensitive marine habitats. Recovery of these ecosystems is limited by slow regrowth. Anchoring pressure on coastal seabed habitats was estimated using AIS (Automatic Identification System) data along $1800 \mathrm{~km}$ of Mediterranean coastline between 2010 and 2015. A comparison with field observations showed that these results were most consistent for large boats ( $>50 \mathrm{~m}$ ). An analysis of AIS data coupled with a seabed map showed that around $30 \%$ of the habitats between 0 and $-80 \mathrm{~m}$ exhibited anchoring pressure. Posidonia oceanica seagrass beds were the most impacted habitat in terms of duration. This methodology efficiently estimates spatial and temporal anchoring pressure principally due to large boats and should interest managers of marine protected areas as much as coastline managers.

Key words: mooring impact; benthic habitats; ship; method; habitat vulnerability; resilience

\section{INTRODUCTION}

Global shipping (maritime transport and recreational boating) is an important sea use and has significant economic value. A recent review of maritime transport reported that "around $80 \%$ of global trade by volume and over $70 \%$ of global trade by value are carried by sea and are handled by ports worldwide" (United Nations Conference on Trade and Development (UNCTAD), 2015). The studied ships comprise commercial vessels (passenger and/or goods transport, service and assistance, professional use such as fishing, or research) and recreational vessels. Recreational boating represents a large number of users with $29 \%$ (34.2 million) of U.S. households having at least one member who boated in 2011 (USCG boating, 2011), and Europe having 36 million boaters and six million boats in its waters (European Boating Industry, 2010). There are numerous adverse environmental effects from this high number of boats: collision, pollution (e.g., ballast, oil, antifouling products), devoted buildings on land (harbours) and anchoring (Cappato, 2011). Anchoring is defined as the short-term deployment of a physical device to hold fast to the substrate by a vessel (Kininmonth et al., 2014). Anchoring is responsible for mechanical disturbance of highly sensitive marine habitats like seagrass meadows (Short and Wyllie-Echeverria, 1996) and biogenic reefs (Ballesteros, 2006; Davis, 1977), whose recovery is limited by slow regrowth. Concentrated in shallow waters by its very nature, anchoring causes direct and indirect damage to some of the most valuable marine ecosystems (Costanza et al., 1997; Forrester et al., 2015) through deployment and retrieval of the anchor and the movement of the attached chain/rope (Milazzo et al., 2004; Walker et al., 2012). Concentrated on shallow waters by its very nature, anchoring causes direct and indirect damages to some of the most valuable marine ecosystems (Costanza et al., 1997; Forrester et al., 
2015) through deployment and retrieval of the anchor and the movement of the attached chain/rope. These ecosystems have already suffered serious decline from man-made coastline, landbased pollutants and climate change (Coll et al., 2012; Forrester et al., 2015; Hughes et al., 2003; Waycott et al., 2009). Locating and quantifying areas of anchoring pressure is an essential, basic step in a multiple-use zoning approach, avoiding conflicting use of zones and facilitating impact management. Anchoring pressure has been the subject of local studies based on direct observations (Francour et al., 1999), aerial photography (Bonhomme et al., 2013; F. Holon et al., 2015) or models combining geophysical, ecological, and social components (Kininmonth et al., 2014).

Automatic identification systems (AIS) can help to locate and quantify anchoring pressure. AIS are designed to provide information about the ship to other ships and to coastal authorities automatically. Since $31^{\text {th }}$ December 2004, the regulation requires "AIS to be fitted aboard all ships of 300 gross tonnage and upwards engaged on international voyages, cargo ships of 500 gross tonnage and upwards not engaged on international voyages and all passenger ships irrespective of size" for safety reasons (International Maritime Organization, 2016). Data are exchanged between ships, terrestrial AIS bases and satellites. Most of the pleasure boats are not concerned by the regulation as they are shorter than $24 \mathrm{~m}$ (Direction générale des infrastructures, des transports et de la mer, 2015) and a few of them are expected to voluntarily use an AIS.

This work outlines a new method of using data from this automatic tracking system to locate and quantify anchoring pressure along $1800 \mathrm{~km}$ of coastline over six years. The impact of this pressure is outlined using a seabed habitat map (11 classes including seagrass and biogenic reefs). A comparison of these results with aerial and land-based observations is performed to estimate the bias of AIS data.

\section{MATERIAL AND METHODS}

1.1. Study area and existing seabed maps

This work considers the whole Mediterranean French coast including Corsica i.e., $1800 \mathrm{~km}$ coastline between 0 and $-80 \mathrm{~m}$. This area was chosen to take advantage of an existing seabed habitat map. This 1:10 000 seabed habitat map (between 0 and $-80 \mathrm{~m}$ ) was freely obtained from the "DONIA Expert" project, hosted by the cartographic platform Medtrix (www.medtrix.fr). This continuous map was built in 2014 using a combination of aerial pictures, multi-beam echosounder data, side-scan sonar data and direct observations ("ground-truth points") by divers (Holon et al., 2015; Holon, 2015). Eleven habitat classes were considered: Cymodocea nodosa seagrass, Posidonia oceanica seagrass, dead matte association, infralittoral shingle association, infralittoral soft bottoms, photophilous algae association, coralligenous reefs (= biogenic reefs), circalittoral soft bottoms, artificial habitats, offshore rocks and the bathyal zone. Dead matte association is the habitat resulting from the death of $P$. oceanica seagrass beds (Boudouresque et al., 2012).

\subsection{AIS ship data pre-treatment}

For this work, AIS data were purchased from MarineTraffic.com for a six-year period from 2010 to 2015 along the Mediterranean French coastline. No data prior to 2010 were available. Our request concerned data received by terrestrial AIS bases with an hourly frequency for vessels declared as "anchored". The dataset contained the following fields for over two million (2145523) AIS positions: vessel identity (Maritime Mobile Service Identity - MMSI), speed, position (longitude and latitude), course, heading, timestamp and vessel length. Vessel length was found to be unusable because of a high number of null, missing or incorrect data because this field is manually recorded when AIS is installed.

First, anchoring positions were localised and vessels that were not anchored (false positives) were removed if they did not meet the following conditions: speed $<1$ knot, distance between the hourly AIS points $\leq 600 \mathrm{~m}$ (300-meters-long vessels are now common in maritime transport) and AIS points per vessel $\geq 4$. Anchored vessels are generally not totally immobile and often drift with current, wind and/or swell around the anchor according to a circle or an arc of a circle pattern (Figure 1). A regression 
circle and its centre were defined as the anchoring position for each vessel using the "Isfit.circle" function of the Circular v.0.4-7 package (Agostinelli and Lund, 2013) with R version 3.2.4 (R Core Team 2015). In the case of the radius being higher than $600 \mathrm{~m}$ (highly clustered points or aligned points) or when the centre was positioned on land or within harbours ("harbour" layer obtained from (Meinesz et al., 2010)), the centroid, instead of the centre of the circle, was taken as the anchoring position. It was also verified that no anchoring points were identified within the 27 equipped mooring areas declared and controlled by prefectural decrees. 
a)

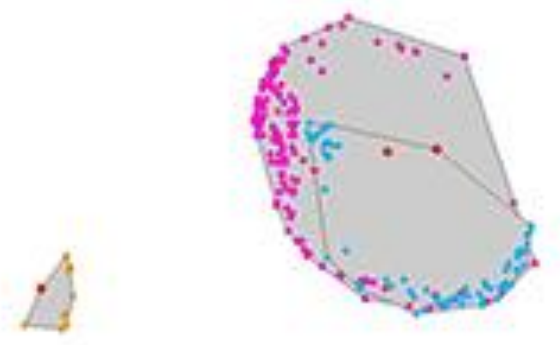

A
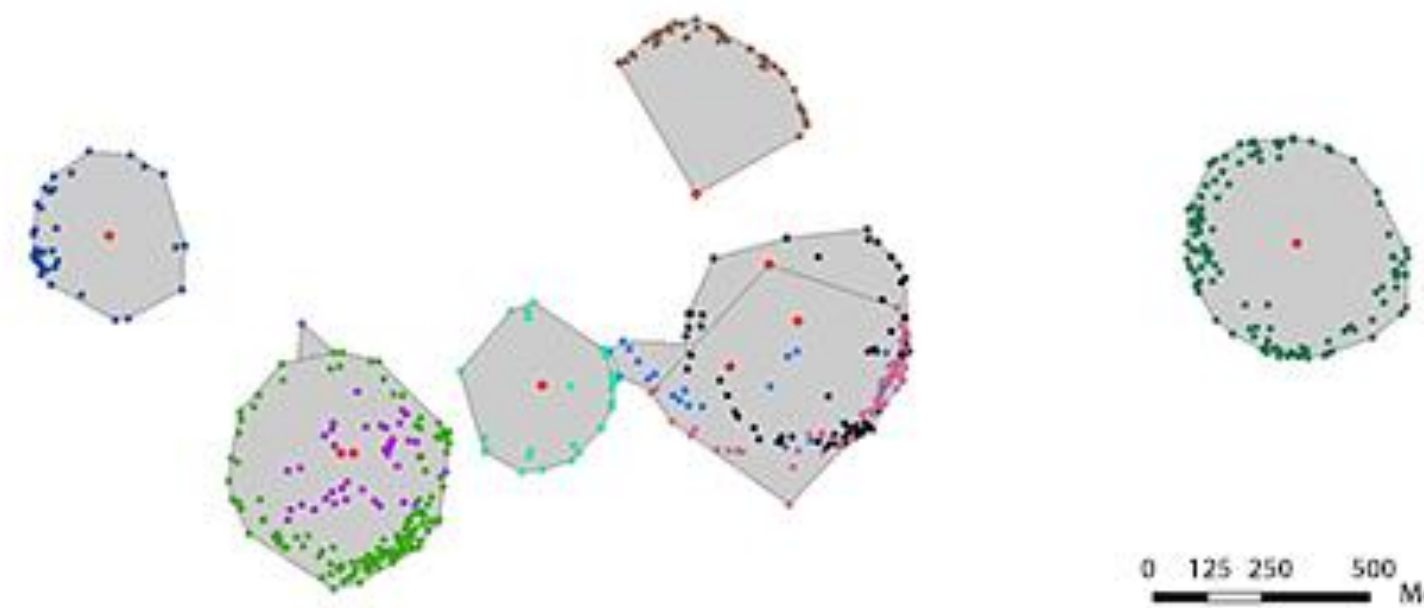

b)
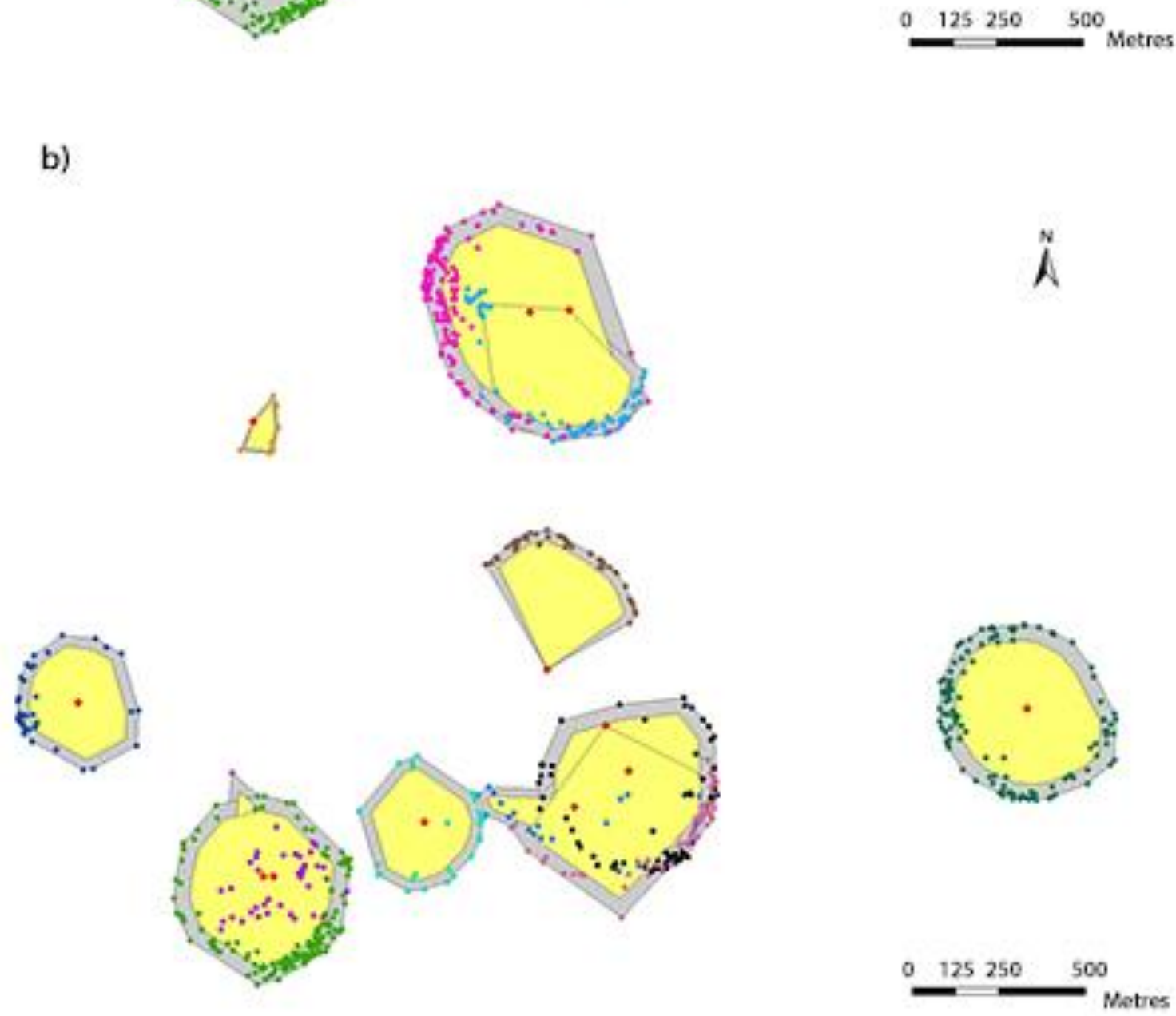

Figure 1. Examples of anchoring zones (grey) and anchoring impact areas (yellow). a) Anchoring areas (grey) are determined from AIS data. Each colour represents a different anchoring. Estimated anchoring positions are 
presented in red. b) Anchoring zone was reduced of one third in a concentric manner to define anchoring impact areas.

\subsection{Anchoring impact analysis}

An anchoring zone was defined as a polygon including the anchoring position of a vessel and its AIS points. Anchoring zones partly covering land or harbours were removed from the dataset. The area of each anchoring zone was reduced by one third in a concentric manner to remove the chain length placed in the water column and to define the anchoring impact area (Figure 1) (Boudouresque et al., 2012). Anchoring duration was calculated based on the first and last AIS points (date and time) used to define the area. A grid composed of $20 \times 20 \mathrm{~m}$ cells was applied and the duration was divided by the area of the anchoring zone and multiplied by the area of cell occupied by the anchoring zone polygon to determine a proportional anchoring duration per cell $\left(400 \mathrm{~m}^{2}\right)$. Anchoring density was studied through the number of anchored vessels per cell and per year as well as the time interval between two anchorings. Combining this with the seabed habitat map allows studying the impact of anchoring (range, duration, seasonality) on these habitats. This part of the work was performed using ArcMap version 10.0 and Qgis 2.13.3.

\subsection{Comparison between AIS and observation data}

To estimate the bias of AIS data, it was compared with existing field observations. Anchored vessels were counted and their length estimated in the framework of two studies: i) from the coastline at 12 h00 UTC over 21 days (15 May - 30 September) in 2014 between the capes of Nice and Ail (Meinesz and Miranda, 2014) and ii) from a plane over three days (26 July $12 \mathrm{~h} 55 \mathrm{pm}$ to $1 \mathrm{~h} 20 \mathrm{pm}, 10$ August $11 \mathrm{~h} 14$ am to $11 \mathrm{~h} 22$ am UTC and 25 September 09h52 am to 09h56 am UTC) in 2014 (MEDOBS project, http://medtrix.fr). These data were compared with AIS data obtained from the same days, within the same areas and time slots through analyses of variance (ANOVAs).

\section{RESULTS}

The database obtained from Marine Traffic contained data from 12447 different vessels (around 2000 different vessels per year over six years). After the pre-treatment, and after removing any anchoring zones partly covering harbours or land, 60097 anchoring impact areas were analysed for a total cumulated impact area of 79214.99 ha (median $\left.=3964.33 \mathrm{~m}^{2}\right)$. This corresponded to 5868 different vessels (around 1800 per year) for 2065457 AIS positions (Table 1). During the study (20102015), the highest number of anchored vessels was observed between May and September with maximal values in July (12623) and August (12770) (Figure 2). Anchoring lasted for an average of 27.63 hours (median $=14.55 \pm 47.07$ ) and was observed at an average of $-20 \mathrm{~m}$. Most of the anchored time was spent during the night ( 883530 hours compared with 779401 hours during the daytime). The annual cumulated anchoring durations were similar each year (Anova: $F=0.73 ; P=0.60$ ), in contrast to cumulated anchoring impact areas which varied by year $(F=198.87 ; P<0.001)$ with the total highest impact area found in 2010. Each grid cell hosted an average of 1.15 anchored vessels per grid cell $(20 \times 20 \mathrm{~m})$ per year (no significant variation between years; $F=651.23, P<0.001$ ) with a maximum of 26 vessels per cell observed in 2015. The interval between two anchorings within one grid cell varied from $0.04 \mathrm{~h}$ to $8886.71 \mathrm{~h}$ ( 370 days) with a mean interval of $1350.56 \mathrm{~h}$ (median $=997.62 \pm 1284.42$ h), i.e., 56 days.

Table 1. Anchoring data analysis per year. Areas were calculated using a $20 \times 20 \mathrm{~m}$ grid cell.

\begin{tabular}{cccccc}
\hline Year & $\begin{array}{c}\text { Number } \\
\text { of } \\
\text { anchored } \\
\text { vessels }\end{array}$ & $\begin{array}{c}\text { Number of } \\
\text { different } \\
\text { vessels }\end{array}$ & $\begin{array}{c}\text { Cumulated } \\
\text { anchoring } \\
\text { impact } \\
\text { area in ha }\end{array}$ & $\begin{array}{c}\text { Anchoring } \\
\text { mean } \\
\text { duration in } \\
\text { hours } \\
\text { (standard } \\
\text { error) }\end{array}$ & $\begin{array}{c}\text { Cumulated } \\
\text { anchoring } \\
\text { duration in } \\
\text { hours }\end{array}$ \\
\hline 2010 & 7239 & 1822 & 6893.44 & $1.51(2.03)$ & 259527.43
\end{tabular}




\begin{tabular}{lccrrr}
$\mathbf{2 0 1 1}$ & 9395 & 1841 & 5820.80 & $1.70(2.63)$ & 247846.09 \\
$\mathbf{2 0 1 2}$ & 10358 & 1790 & 6238.08 & $1.73(2.77)$ & 269215.95 \\
$\mathbf{2 0 1 3}$ & 11219 & 1818 & 6846.68 & $1.64(2.63)$ & 280130.79 \\
$\mathbf{2 0 1 4}$ & 10888 & 1860 & 6664.24 & $1.61(2.51)$ & 268313.16 \\
$\mathbf{2 0 1 5}$ & 10998 & 1899 & 6553.48 & $1.56(2.43)$ & 256112.12 \\
\hline Total & 60097 & 5868 & 15219.88 & $4.16(7.90)$ & 1581145.52 \\
\hline
\end{tabular}

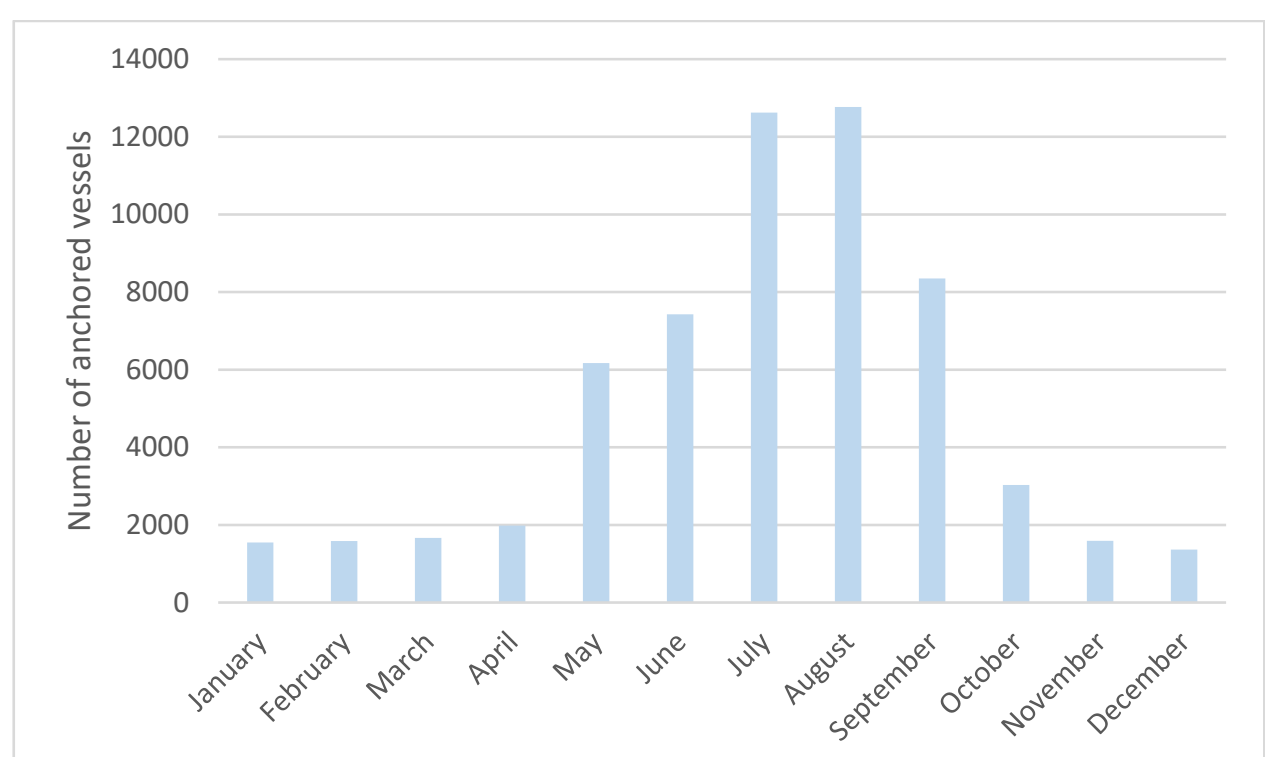

Figure 2. Anchoring seasonality based on AIS data (all years from 2010 to 2015 were considered).

Most of the anchoring density was located east of the mainland coastline ( $99 \%$ of the total impact area) with four zones having $80.7 \%$ of the total impact areas: Fos-sur-mer, Cannes/GolfeJuan/Antibes, Beaulieu / Villefranche-sur-mer and Saint-Tropez (Figure 3Erreur ! Source du renvoi introuvable.). 
Figure 3. Anchoring pressure density (all the anchoring impact areas are overlaid) along the Eastern Mediterranean French coastline between 2010 and 2015. The four zoomed areas show the most impacted seabeds. The scale varies between 0 and 100 where 100 corresponds to the maximal number of overlaid areas.

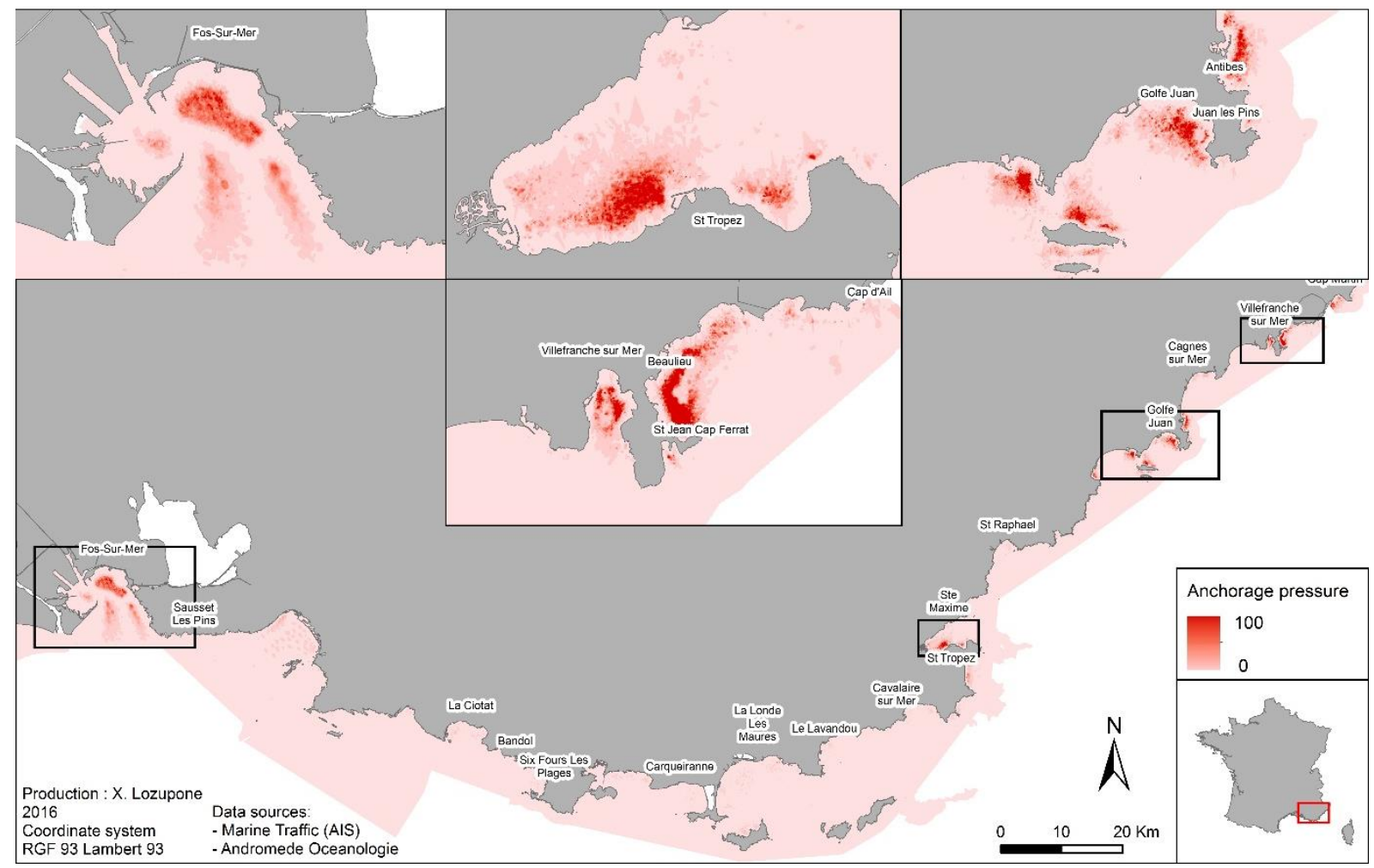

Between 0 and $-80 \mathrm{~m}$, almost one third $(29.49 \%)$ of the seabed habitats were subjected to anchoring pressure between 2010 and 2015 (Table 2). The most impacted habitats (in terms of areas) were circalittoral soft bottom (6 022 ha), infralittoral soft bottom (4 488 ha) and P. oceanica seagrass ( 3772 ha). Proportionally to its presence along the coastline, $P$. oceanica dead matte association was the most impacted habitat ( $11.13 \%)$ followed by $C$. nodosa seagrass $(5.27 \%)$ and $P$. oceanica seagrass $(4.52 \%)$. In terms of duration, $P$. oceanica seagrass beds were also the most occupied habitats $(36.40$ hours of anchoring/ha/year) (Table 2). 
Table 2. Anchoring pressure analysis of seabed habitats. Areas were calculated using a $20 \times 20 \mathrm{~m}$ grid cell.

\begin{tabular}{|c|c|c|c|c|c|}
\hline Marine habitats & $\begin{array}{c}\text { Total habitat } \\
\text { area (ha) }\end{array}$ & $\begin{array}{c}\text { Area } \\
\text { subjected } \\
\text { to } \\
\text { anchoring } \\
\text { (ha) }\end{array}$ & $\begin{array}{l}\text { Percent of } \\
\text { habitat } \\
\text { impacted } \\
\text { by } \\
\text { anchoring } \\
\text { (\%) }\end{array}$ & $\begin{array}{l}\text { Anchoring } \\
\text { duration } \\
\text { during the 6- } \\
\text { year study } \\
\text { (hours) }\end{array}$ & $\begin{array}{c}\text { Anchoring } \\
\text { duration / } \\
\text { ha of } \\
\text { impacted } \\
\text { habitat / } \\
\text { year } \\
\text { (hours) }\end{array}$ \\
\hline Infralittoral soft bottom & 117576.16 & 4487.84 & 3.82 & 669857 & 24.88 \\
\hline Circalittoral soft bottom & 446530.61 & 6021.88 & 1.35 & 484191 & 13.40 \\
\hline Coralligenous reefs & 4787.81 & 69.72 & 1.46 & 5910 & 14.13 \\
\hline Artificial habitats & 279.25 & 0.64 & 0.23 & 43 & 11.20 \\
\hline P. oceanica seagrass & 83534.30 & 3771.84 & 4.52 & 262010 & 11.58 \\
\hline $\begin{array}{l}\text { P. oceanica dead matte } \\
\text { association }\end{array}$ & 5980.48 & 665.68 & 11.13 & 145397 & 36.40 \\
\hline $\begin{array}{l}\text { Photophilous algae } \\
\text { association }\end{array}$ & 15339.39 & 149.72 & 0.98 & 10453 & 11.64 \\
\hline Offshore rocks & 858.62 & 2.72 & 0.32 & 201 & 12.32 \\
\hline $\begin{array}{l}\text { infralittoral shingle } \\
\text { association }\end{array}$ & 207.33 & 0.84 & 0.41 & 29 & 5.75 \\
\hline C. nodosa seagrass & 498.28 & 26.28 & 5.27 & 2942 & 18.66 \\
\hline Bathyal zone & 121559.02 & 22.68 & 0.02 & 112 & 0.82 \\
\hline Total & 797151.26 & 15219.84 & 29.49 & 1581145 & 160.77 \\
\hline
\end{tabular}

A comparison with observation data allowed the estimation of the bias of the method (Figure 4). In total, 5572 vessels were observed by counting from the coast (Meinesz and Miranda, 2014) while 299 vessels were counted from AIS data at the same place and during the same period, i.e. a number 19 times lower. However, the number of large vessels $(>50 \mathrm{~m})$ observed was similar with the number of vessels counted from AIS data (Anova: $\mathrm{F}=0.34 ; \mathrm{P}=0.56$ ). The number of vessels estimated from AIS was also much lower than the number counted by aerial observation (Anova: $F=38.65 ; P<0.01$ ). 
Figure 4. Comparison between the number of anchored vessels estimated from AIS data and vessels counted from the coastline (Meinesz and Miranda, 2014) with a length estimation, and vessels counted from a plane (MEDOBS project, http://medtrix.fr). No length is given for vessels obtained from AIS data or from aerial observation. Data were recorded within the bay of Villefranche-sur-mer and the Cap Ferrat Natura 2000 area.

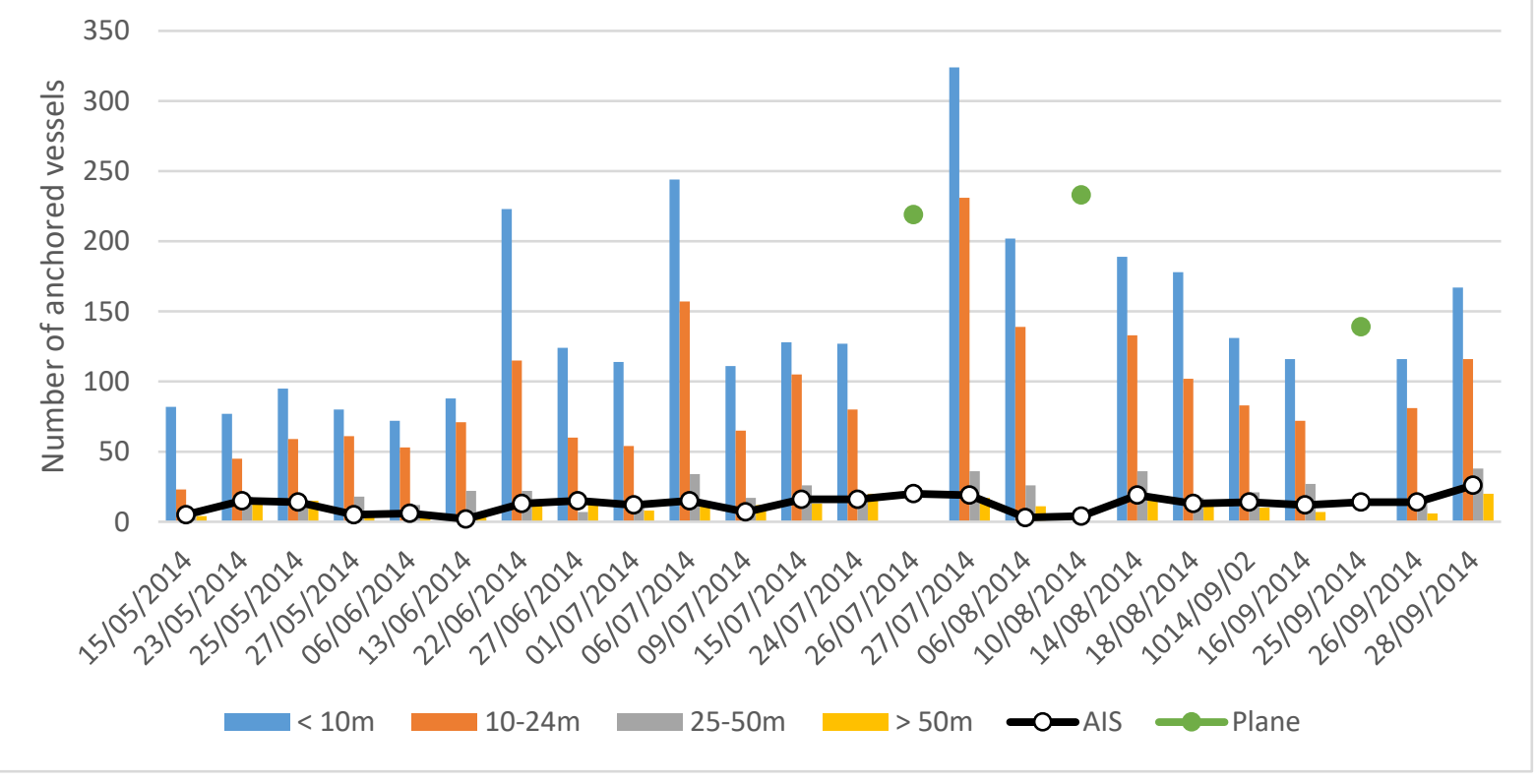

\section{DISCUSSION}

This paper presents, step by step, an effective methodology using AIS data to localise and quantify anchoring pressure in several ways (number of anchored vessels, anchoring impact areas, duration, intervals between anchoring) along a large coastline $(1800 \mathrm{~km})$. AIS produces good quality data for its cost; it allows an automatic pre-treatment and analysis of a large amount of quantitative and accurate data to estimate anchoring positions and impact areas. Contrary to the analysis of satellite imagery, there is no risk of false positives (Pieralice et al., 2014). Based on the present results, there are several possibilities of use: to estimate anchoring pressure from a temporal viewpoint, i.e., time of day, season, year (anchoring was higher during the night and summer) or a spatial viewpoint (several concentration areas were localised to the east of the study zone), and/or in investigating seabed habitats by coupling the results with a seabed habitat map. Anchoring density and time intervals between anchor deployments may also be coupled with the biological resilience of the habitats to better estimate the impact of anchoring pressure. Another huge advantage of our method is that it allows identification of boats, and thus the owners (and captains), origin harbours and frequently used harbours. This is useful information for coastline management as it gives an answer to the question of "where and when to act?". It also provides information for awareness campaigns aimed at changing habits. This type of result might also help influence stakeholders in balancing the economic value brought by boating with the environmental cost. The abundant literature devoted to these questions confirms the interest of managers of marine protected areas (MPA) and coastline managers (Giakoumi et al., 2015; La Manna et al., 2015; Venturini et al., 2016).

However, there is a limitation to AIS, hindering its potential. AIS data only give access to around $1 / 20$ of boat anchorings with a bias in favour of larger ones. These vessels represent a minority of the maritime transport and recreational vessels registered along this coastline (Direction générale des infrastructures, des transports et de la mer, 2015; Ministère de l'Ecologie, du Développement Durable et de l'Energie, 2013). For example in 2015, French Mediterranean coastline counted 404 
854 registered pleasure (motor and sailing) boats, most of them ( $86 \%$ ) were shorter than $8 \mathrm{~m}$ (Direction générale des infrastructures, des transports et de la mer, 2015). However, we envisage that use of AIS will increase and that increasing numbers of ships will be equipped with it in the future, since it provides useful information to vessel captains. In the absence of a global regulation requiring the use of AIS, the data will only be improved by the modernisation of vessels and the goodwill of captains and owners. Large vessels (here high standing pleasure boats and commercial vessels) represent the most important economic value but they also have the biggest anchors and the longest chains and are thus able to produce the greatest damage to seabed habitats. For example, a large $(50 \mathrm{~m})$ vessel anchored overnight on a coral reef caused rapid losses of coral and reef structural complexity, equal to the cumulative decline over 23 years observed at an adjacent site (Forrester et al., 2015). Another limit of this work is that it does not consider the type of anchor and the resulting potential difference to the impact on the seabed (Milazzo et al., 2004). However, the type of anchor and the location of small vessels not equipped with AIS could be provided in the future by smartphone applications like the free DONIA ${ }^{\circledR}$ and Anchor Watch ${ }^{\circledR}$ smartphone applications or others that are provided for a payment like Navionics ${ }^{\circledR}$.

Finally, this present work provides important data for seabed habitat conservation. One-third of the coastal seabed ( 0 to $-80 \mathrm{~m}$ ) is used for anchoring by big vessels, with more than $80 \%$ of these impact areas distributed among four small zones in the east. Three of these zones contain tourist activities while the last zone (Fos-sur-mer) contains commercial boats waiting to unload. Despite this localised intense "parking" use, no regulations or mooring equipment do exist within these areas. However, this is beginning to change with, for example, a lighted buoyed mooring area project near St Tropez (Commune de Ramatuelle, 2016) and the new prefectoral decree $N^{\circ} 155 / 2016$ that controls the mooring of vessels longer than $45 \mathrm{~m}$ in French inshore and territorial waters (Préfecture maritime de Méditerranée, 2016). The latter falls within three European Framework directives (Marine Strategy Framework Directive of 17 June 2008 (2008/56/EC), Water Framework Directive (2000/60/EC) and the "Habitats" directive (92/43/CEE)) aimed at preserving habitats and species of community interest, including $P$. oceanica. Our results show that $P$. oceanica seagrass beds are the most impacted habitat in terms of duration ( 36.40 hours of anchoring/ha/year) and also one of the three most impacted habitats in terms of area proportional to their seabed cover (4.52\%). Seagrass beds are, proportional to their presence, the most impacted habitat: around $10 \%$ of impacted areas consisted of living seagrass beds and around $11 \%$ consisted of dead seagrass beds (dead matte). The impact of anchoring on seagrass beds has already been highlighted by less accurate global analysis of aerial images (Florian Holon et al., 2015). This highly fragile habitat has been greatly studied for its sensitivity to anchoring pressure (Boudouresque et al., 2012; Francour et al., 1999; Milazzo et al., 2004; Montefalcone et al., 2008) and the consequences of anchors and anchoring chain systems during boat drift means dead matte lines and 'furrows' are visible underwater by sonar and aerial views (Abadie et al., 2016, 2015; Holon et al., 2015). Our study shows that a grid cell $\left(400 \mathrm{~m}^{2}\right.$ ) receives an anchor deployment every 56 days on average and 370 consecutive days was the maximal period free from anchoring. These are minimal values as small vessels are largely underestimated and generally anchored at shallower depths than large vessels. This is insufficient to permit a habitat to recover, especially in the case of $P$. oceanica meadow (a protected habitat and plant) whose average horizontal progression is no more than 3-4 cm per year (Boudouresque et al., 2012). For example, meadows destroyed during the second world war are still not completely recolonised 80 years later (Holon et al., 2015). This sensitive habitat faces other stressors (e.g., climate change and pollution from waste waters) and how synergistic, antagonistic or additive the combined effects of these stressors are remains undetermined. In the meantime, it is important to improve human behaviours as this study shows that large boats still anchor within highly sensitive habitats, despite equipment that could help them to avoid these areas. The problem could be that captains either do not know which seabed habitat they occupy during the mooring and that seabed habitats are not similarly sensitive (and that some of them are even protected), or are uninterested in seabed habitat sensitivity (Balaguer et al., 2011; Lloret et al., 2008) because they do not risk anything if they damage 
a protected habitat by using their anchor. Enhancing the broadcast of seabed habitat maps to sea users (see a first initiative through the free $\mathrm{DONIA}^{\circledR}$ application) and well-adjusted awareness campaigns could help to improve these points. Even if it is not their aim, AIS data may help to detect and identify, at the time or afterward, vessels that do not respect the law and damage protected habitats. These vessels could be targeted for education actions.

\section{Acknowledgement:}

This study was partly funded by the French Water Agency (Agence de l'eau Rhône-MéditerranéeCorse). The authors thank Gwenaelle Delaruelle (Andromède océanologie) for her help with data provided by the Medtrix platform especially for the habitats maps (DONIA expert data) and CathyAnna Valentini-Poirier (Agence de l'eau RMC) for her help with MEDOBS data. They also thank Marine Boursault (Andromède océanologie) who obtained the location of equipped mooring areas declared and controlled by prefectural decrees and Guilhem Marre (Andromède océanologie) who analysed the time interval data.

\section{References}

Abadie, A., Gobert, S., Bonacorsi, M., Lejeune, P., Pergent, G., Pergent-Martini, C., 2015. Marine space ecology and seagrasses. Does patch type matter in Posidonia oceanica seascapes? Ecological Indicators 57, 435-446. doi:10.1016/j.ecolind.2015.05.020

Abadie, A., Lejeune, P., Pergent, G., Gobert, S., 2016. From mechanical to chemical impact of anchoring in seagrasses: The premises of anthropogenic patch generation in Posidonia oceanica meadows. Marine Pollution Bulletin 109, 61-71. doi:10.1016/j.marpolbul.2016.06.022

Agostinelli, C., Lund, U., 2013. R package "circular": Circular Statistics (version 0.4-7). URL https://rforge.r-project.org/projects/circular/ [WWW Document]. URL https://r-forge.rproject.org/projects/circular/

Balaguer, P., Diedrich, A., Sardà, R., Fuster, M., Cañellas, B., Tintoré, J., 2011. Spatial analysis of recreational boating as a first key step for marine spatial planning in Mallorca (Balearic Islands, Spain. Ocean \& Coastal Management 54, 241-249.

Ballesteros, E., 2006. Mediterranean coralligenous assemblages: a synthesis of present knowledge. Oceanography and Marine Biology: An Annual Review 44, 123-195.

Bonhomme, P., Bonhomme, D., Frachon, N., Boudouresque, C.-F., Borocco, S., Bricout, R., Schohn, T., Imbert, T., Ruitton, S., 2013. A method for assessing anchoring pressure. Presented at the 40th CIESM congress, Marseille.

Boudouresque, C.-F., Bernard, G., Bonhomme, P., Charbonnel, E., Diviacco, G., Meinesz, A., Pergent, G., Pergent-Martini, C., Ruitton, S., Tunesi, L., 2012. Protection and conservation of Posidonia oceanica meadows. RAMOGE and RAC/SPA publisher, Tunis.

Cappato, A., 2011. Cruises and recreational boating in the Mediterranean. Plan bleu- UNEP/MAP regional activity centre, Nice Sophia Antipolis.

Coll, M., Piroddi, C., Albouy, C., Ben Rais Lasram, F., Cheung, W.W.L., Christensen, V., Karpouzi, V.S., Guilhaumon, F., Mouillot, D., Paleczny, M., Palomares, M.L., Steenbeek, J., Trujillo, P., Watson, R., Pauly, D., 2012. The Mediterranean Sea under siege: spatial overlap between marine biodiversity, cumulative threats and marine reserves: The Mediterranean Sea under siege. Global Ecology and Biogeography 21, 465-480. doi:10.1111/j.1466-8238.2011.00697.x

Commune de Ramatuelle, 2016. Anchorage in the Pampelonne bay.

Costanza, R., D’Arge, R., De Groot, R., Farber, S., Grasso, M., Hannon, B., Limburg, K., Naeem, S., O'Neill, R.V., Paruelo, J., Raskin, R.G., Sutton, P., van Den Belt, M., 1997. The value of the world's ecosystem services and natural capital. Nature 387, 253-260. doi:http://dx.doi.org/10.1038/387253a0.

Davis, G.E., 1977. Anchor damage to a coral reef on the coast of Florida. Biological Conservation 11, 29-34. 
Direction générale des infrastructures, des transports et de la mer, 2015. Le secteur économique de la plaisance. Statistiques 2015 [WWW Document]. Ministère de l'Environnement, de l'Energie et de la Mer. URL http://www.developpementdurable.gouv.fr/IMG/pdf/plaisqqc2015c.pdf (accessed 7.15.16).

European Boating Industry, 2010. European boating industry: facts and figures [WWW Document]. URL http://www.europeanboatingindustry.eu/facts-and-figures

Forrester, G.E., Flynn, R.L., Forrester, L.M., Jarecki, L.L., 2015. Episodic disturbance from boat anchoring is a major contributor to, but does not alter the trajectory of long-term coral reef decline. PloS one 10, e0144498.

Francour, P., Ganteaume, A., Poulain, M., 1999. Effects of boat anchoring in Posidonia oceanica seagrass beds in the Port-Cros National Park (north-western Mediterranean Sea). Aquatic Conservation: Marine and Freshwater Ecosystems 9, 391-400.

Giakoumi, S., Brown, C.J., Katsanevakis, S., Saunders, M.I., Possingham, H.P., 2015. Using threat maps for cost-effective prioritization of actions to conserve coastal habitats. Marine Policy 61, 95102. doi:10.1016/j.marpol.2015.07.004

Holon, F., 2015. Interactions entre écosystèmes marins et pressions anthropiques. Applications au suivi et à la gestion des eaux côtières de la mer Méditerranée. University of Montpellier, France.

Holon, F., Boissery, P., Guilbert, A., Freschet, E., Deter, J., 2015. The impact of 85 years of coastal development on shallow seagrass beds (Posidonia oceanica L. (Delile)) in South Eastern France: A slow but steady loss without recovery. Estuarine, Coastal and Shelf Science 165, 204-212. doi:10.1016/j.ecss.2015.05.017

Holon, F., Mouquet, N., Boissery, P., Bouchoucha, M., Delaruelle, G., Tribot, A.-S., Deter, J., 2015. Fine-Scale Cartography of Human Impacts along French Mediterranean Coasts: A Relevant Map for the Management of Marine Ecosystems. PLOS ONE 10, e0135473. doi:10.1371/journal.pone.0135473

Hughes, T.P., Baird, A.H., Bellwood, D.R., Card, M., Connolly, S.R., Folke, C., Grosberg, R., HoeghGuldberg, O., Jackson, J.B.C., Kleypas, J., others, 2003. Climate change, human impacts, and the resilience of coral reefs. science 301, 929-933.

International Maritime Organization, 2016. AIS transponders [WWW Document]. International Maritime Organization. URL http://www.imo.org/fr/OurWork/Safety/Navigation/Pages/AlS.aspx (accessed 10.7.16).

Kininmonth, S., Lemm, S., Malone, C., Hatley, T., 2014. Spatial vulnerability assessment of anchor damage within the Great Barrier Reef World Heritage Area, Australia. Ocean \& Coastal Management 100, 20-31. doi:10.1016/j.ocecoaman.2014.07.003

La Manna, G., Donno, Y., Sarà, G., Ceccherelli, G., 2015. The detrimental consequences for seagrass of ineffective marine park management related to boat anchoring. Marine Pollution Bulletin 90, 160-166. doi:10.1016/j.marpolbul.2014.11.001

Lloret, J., Zaragoza, N., Caballero, D., Riera, V., 2008. Impacts of recreational boating on the marine environment of Cap de Creus (Mediterranean Sea). Ocean and Coastal Management 51, 749754.

Meinesz, A., Chancollon, O., Garcia, D., Markovic, L., 2010. Côtes méditerranéennes françaises, inventaire Observatoire de l'impact des aménagements construits sur la mer. Rapport final. Laboratoire ECOMERS - Université de Nice-Sophia Antipolis ECOMERS-UNSA publ., Nice.

Meinesz, C., Miranda, J., 2014. Document d'objectifs du site Natura 2000 FR 9301996 « Cap Ferrat » Tome 0 - Etude de fréquentation au mouillage - période estivale 2014. Métropole Nice Côte d'Azur.

Milazzo, M., Badalamenti, F., Ceccherelli, G., Chemello, R., 2004. Boat anchoring on Posidonia oceanica beds in a marine protected area (Italy, western Mediterranean): effect of anchor types in different anchoring stages. Journal of Experimental Marine Biology and Ecology 299, 51-62. doi:10.1016/j.jembe.2003.09.003 
Ministère de l'Ecologie, du Développement Durable et de l'Energie, 2013. Flotte de commerce sous pavillon Français. Etat au 1er Janvier 2013 (Statistiques). Paris.

Montefalcone, M., Chiantore, M., Lanzone, A., Morri, C., Albertelli, G., Bianchi, C.N., 2008. BACI design reveals the decline of the seagrass Posidonia oceanica induced by anchoring. Marine Pollution Bulletin 56, 1637-1645.

Pieralice, F., Proietti, R., La Valle, P., Giorgi, G., Mazzolena, M., Taramelli, A., Nicoletti, L., 2014. An innovative methodological approach in the frame of Marine Strategy Framework Directive: A statistical model based on ship detection SAR data for monitoring programmes. Marine Environmental Research 102, 18-35. doi:10.1016/j.marenvres.2014.07.006

Préfecture maritime de Méditerranée, 2016. Arrêté préfectoral N¹55/2016 réglementant le mouillage des navires dans les eaux intérieures et territoriales françaises de Méditerranée [WWW Document]. URL https://www.premar-mediterranee.gouv.fr/arretes.html (accessed 9.1.16).

Short, F.T., Wyllie-Echeverria, S., 1996. Natural and human-induced disturbance of seagrasses. Environmental Conservation 23, 17-27.

United Nations Conference on Trade and Development (UNCTAD), 2015. Review of maritim transport 2015. UNCTAD/RMT/2015, New York and Genova.

USCG boating, 2011. 2011 National recreational boating Survey.

Venturini, S., Massa, F., Castellano, M., Costa, S., Lavarello, I., Olivari, E., Povero, P., 2016. Recreational Boating in Ligurian Marine Protected Areas (Italy): A Quantitative Evaluation for a Sustainable Management. Environmental Management 57, 163-175. doi:10.1007/s00267015-0593-y

Walker, B., Gilliam, D.S., Dodge, R.E., Walczak, J., 2012. Dredging and shipping impacts on southeast Florida coral reefs. Presented at the 12th International Coral Reef Symposium, p. 5.

Waycott, M., Duarte, C.M., Carruthers, T.J., Orth, R.J., Dennison, W.C., Olyarnik, S., Calladine, A., Fourqueran, J.W., Heck, K.L., Hughes, A.R., others, 2009. Accelerating loss of seagrasses across the globe threatens coastal ecosystems. Proceedings of the National Academy of Sciences 106, 12377-12381. 